\title{
EFEK NEUROPROTEKTIF CEFTRIAXONE DENGAN MENINGKATKAN EKSPRESI GLT-1PADA CIDERA KEPALA: SEBUAH KAJIAN SISTEMATIS
}

\author{
Baiq Anggia Azzahra Halba, Abiyyu Didar Haq, Alifia Firdiansari, Harie \\ Sagita Novendi \\ Fakultas Kedokteran, Universitas Mataram, Nusa Tenggara Barat, Indonesia. \\ Email: anggiaazzahra30@gmail.com, abiyyudidarhaq@gmail.com, \\ firdiansarialifia@gmail.com, harienovendi037@gmail.com
}

\begin{abstract}
Abstrak
Cidera otak atau cidera kepala merupakan kasus trauma ketiga paling sering ditemukan di indonesia dengan prevalensi sebesar 11,9\% pada tahun 2018. Kerentanan terhadap infeksi yang meningkatpada kebanyakan kasus cidera otak membuat penggunaan antibiotik menjadi sangat masuk akal pada kasus - kasus tersebut. Salah satu antibiotik yang memiliki kemampuan penetrasi sawar darah-otak yang terbukti sangat baik adalah ceftriaxone. Baru - baru ini, mulai dilakukan penelitian yang membahas tentang efek neuroprotektif dari ceftriaxone terhadap cidera otak yaitu meningkatkan ekspresi GLT-1 yang menguatkan rasional pemberian ceftriaxone pada kasus cidera otak. Namun, belum ada kajian mengenai efektivitasnyabelum ditemui. Tujuan dari penulisan artikel ini adalah untuk mengevaluasi efektivitas pemberian ceftriaxone terhadap peningkatan kadar GLT-1 pada kasus cidera otak. Metode penulisan dilakukan dengan kajian sistematik menelusuri berbagai pusat data daring mengikuti alur dan kaidah pencarian PRISMA guna mencari studi-studi yang menguji kemampuan dari ceftriaxone dalam meningkatkan kadar GLT-1 pada kasus cidera otak. Kajian ini melibatkan 5 studi inklusi dari total 722 studi dengan total subjek sebanyak 362 sampel. Berdasarkan studi inklusi tersebut, didapatkan bahwa Pemberian ceftriaxone $(200 \mathrm{mg} / \mathrm{kgBB})$ terbukti efektif dalam meningkatkan kadar GLT-1 1-7 hari post-trauma jika dibandingkan dengan kelompok kontrol. Edema serebral juga mengalami perbaikan pada kelompok yang diberikan ceftriaxone jika dibandingkan dengan kelompok kontrol. Selain itu, didapatkan juga peningkatan kemampuan pembelajaran dan daya ingat post-trauma pada kelompok intervensi. Tidak ada efek samping signifikan yang dilaporkan.
\end{abstract}

Kata Kunci: Cidera Otak; Antibiotik; Ceftriaxone; Neuroprotektif; GLT-1.

\begin{abstract}
Brain injury or head injury is the third most common trauma case in Indonesia with a prevalence of $11.9 \%$ in 2018. The increased susceptibility to infection in most cases of brain injury makes the use of antibiotics very reasonable in these cases. One of the antibiotics that has the ability to penetrate the blood-brain barrier which is proven to be very good is ceftriaxone. Recently, research has begun to discuss the neuroprotective effect of ceftriaxone on brain injury,
\end{abstract}

Copyright holder: Baiq Anggia Azzahra Halba, Abiyyu Didar Haq, Alifia Firdiansari, Harie Sagita Novendi (2022)

DOI $\quad: 10.54543 /$ fusion.v2i1.129

Published by : Rifa Institute 
Baiq Anggia Azzahra Halba, Abiyyu Didar Haq, Alifia Firdiansari, Harie Sagita Novendi

namely increasing the expression of GLT-1 which strengthens the rationale for giving ceftriaxone in cases of brain injury. However, no studies on its effectiveness have not been found. The purpose of this article is to evaluate the effectiveness of ceftriaxone administration to increase GLT-1 levels in cases of brain injury. The writing method was carried out by a systematic study of browsing various online data centers following the PRISMA search rules and procedures in order to find studies that tested the ability of ceftriaxone in increasing GLT-1 levels in cases of brain injury. This study involved 5 inclusion studies out of a total of 722 studies with a total sample of 362 subjects. Based on the inclusion study, it was found that the administration of ceftriaxone $(200 \mathrm{mg} / \mathrm{kgBW})$ proved to be effective in increasing GLT-1 levels 1-7 days posttraumatic when compared to the control group. Cerebral edema also improved in the group given ceftriaxone when compared to the control group. In addition, there was also an increase in learning ability and post-traumatic memory in the intervention group. No significant side effects were reported.

Keywords: Brain Injury ; Antibiotics; Ceftriaxone; Neuroprotective ; GLT-1

Diterima: 27-10-2021 Direvisi: 11-01-2022_Diterbitkan: 20-01-2022

\section{Pendahuluan}

Cedera kepala adalah cedera mekanikyang secara langsung atau tidak langsung mengenai kepala yang mengakibatkan luka di kulit kepala, fraktur tulang tengkorak, robekan selaput otak dan kerusakan jaringan otak itu sendiri, serta mengakibatkan gangguan neurologis. Cedera kepala terjadi ketika kekuatan eksternal dari suatu peristiwaseperti jatuh, cedera olahraga, kecelakaan kendaraan bermotor, atau ledakan yang melukai otak dan menyebabkan hilangnya kesadaran atau kehilangan memori (Abi Nubli, 2019). Menurut Riskesdas 2018, prevalensi kejadian cedera kepala di Indonesia berada pada angka $11,9 \%$. Cedera pada bagian kepala menempati posisi ketiga setelah cedera pada anggota gerak bawah dan bagian anggota gerak atas dengan prevalensi masing-masing 67,9\% dan 32,7\%. Pada umumnya cedera kepala paling sering terjadi pada anak dengan rentang usia 1-4 tahun dan usia produktivitas (Bahuddin, 2021).

Pasien dengan GCS rendah memiliki kemungkinan terburuk. Bahkan pasien yang masih bertahan dapat mengalami pemulihan yang lama dan beberapa masih tertinggal dengan sisa defisit neurologis. Pemulihan total bisa memakan waktu berbulan-bulan atau bahkan bertahun-tahun (Georges \& Das, 2021). Jika tidak ditangani dengan baik maka penderita cedera kepala sangat rentan mengalami komplikasi, baik sesaat setelah trauma atau beberapa hari setelahnya. Komplikasi yang biasanya terjadi yaitu penurunan kesadaran, kejaang pasca trauma, serta infeksi seperti meningitis (Georges \& Das, 2021). Cedera kepala dapat menyebabkan berbagai perubahan kognitif, fisik, dan psikologis yang dapat memengaruhi kehidupan seseorang. Gangguan kejiwaan termasuk suasana hati dan kecemasan sering terjadi setelah cedera otak tertama ketika cedera sedang sampai parah dan mengganggu bagi kesehatan, partisipasi sosial, dan kualitas hidup seseorang (Abi Nubli, 2019). 
Infeksi merupakan suatu konsekuensi dari kontaminasi antara jaringan yang biasanya steril dengan mikroorganisme. Pada kondisi trauma, inokulasi atau perpindahan mikroorganisme terjadi akibat kerusakan barrier alami yang melawan infeksi (Poole et al., 2014). Trauma kepala atau cedera otak traumatis (TBI) secara signifikan meningkatkan kerentanan pasien terhadap infeksi melalui berbagai mekanisme. Sekitar 4\% dari semua cedera kepala merupakan fraktur skull base, dan 90\% dari fraktur ini adalah akibat dari trauma kepala tertutup. Pasien dengan fraktur skull base berisiko tinggi mengalami meningitis karena adanya potensi kontak bakteri antara sinus paranasal, nasofaring, atau telinga tengah dengan sistem saraf pusat. Risiko terjadinya meningitis menjadi lebih tinggi dengan adanya kebocoran cairan serebrospinal (CSF). Penelitian yang dilakukan Yellinek et al., (2016) melaporkan bahwa tingkat meningitis pada pasien dengan fraktur skull base rendah dan penggunaan antibiotik profilaksis tidak diperlukan (Suhery et al., 2016). Infeksi intrakranial seperti meningitis, ensefalitis, dan abses otak merupakan komplikasi relatif yang jarang terjadi setelah cedera otak traumatis, namun memiliki prognosis neurologis yang buruk dan dapat menyebabkan gangguan kognitif pasca cedera kepala traumatis (TBI). Angka kematian terkait infeksi pada cedera kepala kemungkinan sebesar 28\% (Lai et al., 2011).

Penggunaan antibiotik untuk sistem saraf pusat seperti pada kasus cedera kepala harus mampu memiliki mekanisme menembus blood brain barrier (BBB). Kesulitan antibiotik dalam mencapai dosis yang adekuat dalam cairan serebrospinal (CSF) disebabkan oleh ketidakmampuan antibiotik dalam menembus blood brain barrier (BBB) sehingga akan menyebabkan penggunaan antibiotik profilaksis tersebut tidak adekuat (Hidayati, 2015). Pada penelitian meta-analisis dari keseluruhan insiden infeksi intrakranial yang dilakukan oleh Rathmore (1970) menemukan hasil bahwa didapatkan satu insiden yangmenunjukkan manfaat yang signifikan untukpenggunaan antibiotik profilaksis.

Antibiotik laktam, terutama ceftriaxone yang menunjukkan penetrasi sawar darah-otakyang sangat baik. Pemberian ceftriaxone pada cedera kepala dengan infeksi yang disebabkan oleh bakteri Spneumoniae diberikan ceftriaxone dengan total dosis 4 gram/hari. Ceftriaxone dapat memberikan aktivitas yang baik melawan kebanyakan S. pneumoniae yang resisten terhadap penicillin (Estri \& Radiono, 2007).Pada penelitian meta-analisis dari keseluruhan insiden infeksi intrakranial yang dilakukan oleh Rathmore (1970) menemukan hasil bahwa didapatkan satu insiden yang menunjukkan manfaat yang signifikan untuk penggunaan antibiotik profilaksis. Penelitian Ratilal et al., (2015) menemukan sebuah studi terkait dengan penggunaan antibiotik profilaksis yang digunakan untuk pencegahan kasus meningitis pada pasien yang di diagnosis dengan fraktur tulang tengkorak basilar (Farihatini, 2019).

Data CDC tahun 2011 menemukan bahwa pneuomonia terkait ventilator (VAP) merupakan penyebab lain dari pasien dengan infeksi pada cedera kepala, ditemukan bahwa VAP pada pasien cedera kepala sebesar $40 \%$ yang berkaitan dengan intensitas penggunaan ventilasi. VAP menjadi faktor tingginyamorbiditas pada pasien cedera 
Baiq Anggia Azzahra Halba, Abiyyu Didar Haq, Alifia Firdiansari, Harie Sagita Novendi

kepala dengan kejadian hipoksia, demam, hipotensi, dan peningkatan TIK. Infeksi intrakranial setelah cedera kepala disebabkan oleh beberapa organisme, penyebab terbanyak disebabkan karena bakteri staphylococcus aureus. Persentase komplikasi infeksius yang ditemukan pada trauma cedera kepala sebesar $58,8 \%$ sebelum pemberian antibiotik,sehingga dianjurkan untuk menggunakanantibiotik spektrum luas seperti coamoxiclav IV atau cefuroxime IV dengan metronidazole IV harus diberikan pada pasien cedera kepala selama 7-14 hari.

Terdapat berbagai penelitian yang menunjukkan bahwa selain mencegah infeksi, ternyata pemberian antibiotik, terutama ceftriaxone, memiliki efek positif lain yang mampu meningkatkan luaran dari cidera kepala. Salah satu bentuk dari efek perbaikan luaran yang diberikan oleh pemberian ceftriaxone adalah efek neuroprotektif dalam bentuk peningkatan ekspresi transporter glutamat GLT-1 pada otak. Transporter Glutamat-1 atau GLT-1 merupakan transporter utama yang berada di dalam otak dan merupakan $1 \%$ dari seluruh protein yang ada di otak (Rimmele \& Rosenberg, 2016). Transporter ini memainkan peran utama dalam aktivitas uptake glutamat pada sinaps. Oleh karena itu, penelitian yang dilakukan pada tahun 1997 menunjukkan bahwa penghapusan gen yang mengkode GLT-1 akan menghilangkan 95\% kemampuan uptake glutamat di dalam otak (Sepkuty et al., 2002). Hingga saat ini, penelitian yang membahas tentang potensi pemberian ceftriaxone pada cidera kepala untuk meningkatkan ekspresi GLT-1 masih terbatas pada eksperimen pada hewan coba. Oleh karena itu, penulis melakukan kajian secara sistematik terhadap publikasi penelitian yang membahas topik tersebut untuk mengetahui sudah sejauh mana bukti yang ada hingga saat ini sekaligus diharapkan mampu menjadidasar dari kelanjutan penelitian mengenai potensi ceftriaxone di masa yang akan datang.

\section{Metode Penelitian}

\section{Strategi Pencarian Studi}

Empat orang reviewer (A.Z, A.D, A.F, dan H.S) melakukan pencarian studidari berbagai pusat data daring yang valid yaitu PubMed, PubMed Central (PMC), Science Direct, Directory of Open Access Journal, dan Wiley pada tanggal 12 April 2021 mengikuti alur dan kaidah pencarian dari Preferred Reportic System for Systematic Reviews and Meta-analyses (PRISMA) untuk mencari seluruh studi yang mengidentifikasi kinerja ceftriaxone dalam meningkatkan kadar GLT-1 pada cidera kepala. Pencarian studi pada kajian sistematisini menggunakan kata kunci "Ceftriaxone AND (GLT-1 Protein OR GLT-1 OR GLT-1 Expression) AND (Traumatic Brain Injury OR Brain Injury OR Head Injury)".

Studi yang memenuhi syarat untuk masuk ke dalam kriteria kajian sistematis ini adalah studi yang memenuhi kriteria inklusi sebagai beriku: 1) Merupakan studi intervensi (randomized control trial, Non randomized controlled trial, interventional study without concurrent control, before-after study, factorial study, crossover study, dan cluster randomized trial); 2) Publikasi studi dalam bahasa inggrisatau indonesia; 3) Pengujian dilakukan pada manusia maupun hewan coba yang memiliki cidera 
kepala dan/atau individu sehat sebagai kelompok kontrol penelitian; 4) Pengujian studi berupa obat antibiotik tunggal maupun kombinasi; 5) Luaran dari penelitian adalah ekspresi protein GLT-1, lokasi ekspresi GLT-1, dan luaran klinis dari partisipan penelitian. Kami mengeksklusi studi yang memiliki salah satu atua lebih kriteria eksklusi yang kami tetapkan yaitu: 1) Studi yang dilaksanakan dan/atau dipublikasikan sebelum tahun 2010 ; 2) Studi tidak dipublikasi dalam Bahasa Inggris atau Bahasa Indonesia ; 3) Tidak tersedia full text dari penelitian.

\section{Penyaringan Studi}

Penyaringan artikel studi dilakukan oleh empat reviewer (A.D, A.F, A.Z, dan H.S) dalam beberapa tahap. Tahap pertama, dilakukan penyaringan judul dan abstrak studi. Studi yang tidak sesuai dengan kriteria akan dieksklusi sedangkan studi yang memenuhi kriteria akan dilibatkan ke dalam tahap penyaringan yang selanjutnya yaitu tahap penyaringan full-text. Apabila data atau artikel pada studi yang bersangkutan tidak lengkap maka studi tersebut akan dieksklusi. Akhirnya akan tersaring beberapa studi yangakan digunakan pada qualitative synthesis. Detail penyaringan studi dapat dilihat pada

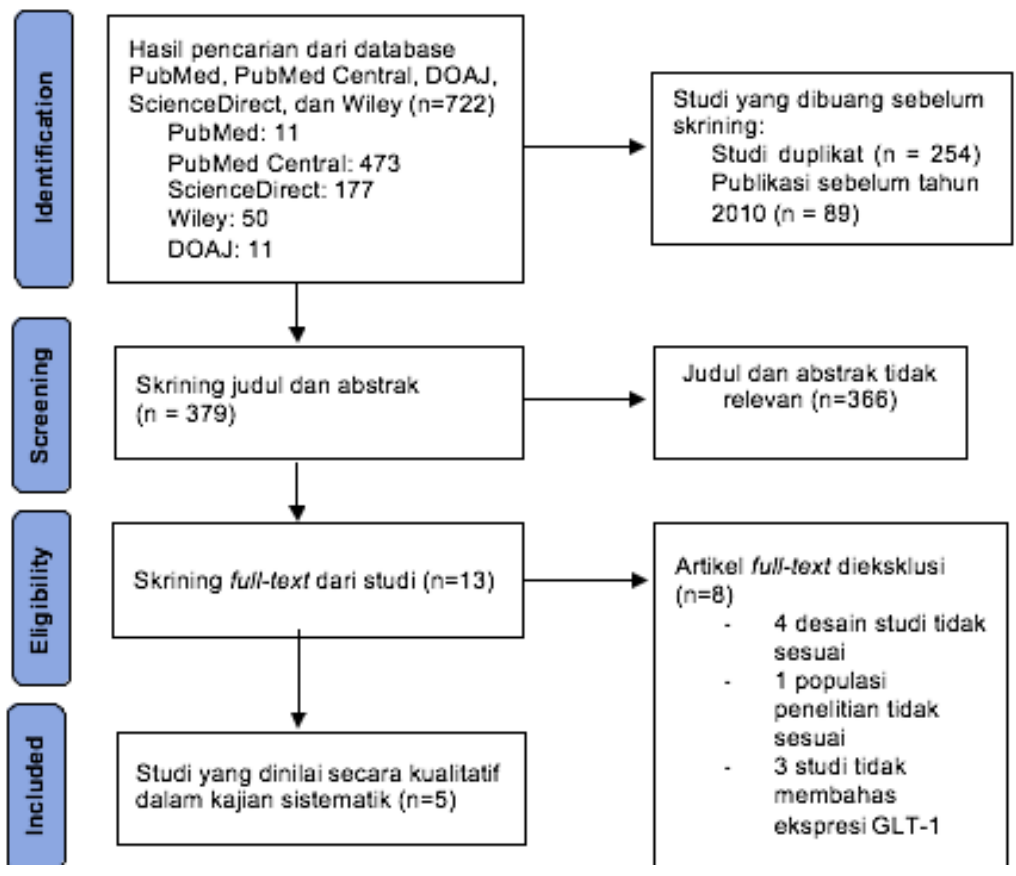

Gambar 1 Strategi Pencarian Literatur

\section{Hasil}

Data dari masing-masing studi yang telah diinklusi dalam kajian sistematis ini kemudian akan dikumpulkan dandimasukkan ke dalam tabel. Data yang diambil dan selanjutnya dimasukkan kedalam tabel tersebut adalah: 1) Karakteristik populasi studi (informasi diagnostik dan ukuran sampel); 2) Jenis antibiotik yang digunakan dalam penelitian tersebut; 3) . Data dikumpulkan oleh satu reviewer (A.D) lalu kemudian disesuaikan kembali oleh tiga reviewer lainnya (A.F, A.Z, dan H.S). Data yang telah 
Baiq Anggia Azzahra Halba, Abiyyu Didar Haq, Alifia Firdiansari, Harie Sagita Novendi

terkumpul nantinya akan disajikandalam bentuk tabel.

\section{A. Hasil Penyaringan Studi}

Pada pencarian studi literatur dengan kata kunci yang sudah ditetapkan, didapatkan sejumlah 722 studi. Selanjutnya, didapatkan 254 literatur duplikat yang dieksklusi. Kemudian, reviewer membaca judul dan abstrak dari 379 studi yang tersisa untuk penyaringan tahap selanjutnya. Pada tahap penyaringan ini, sebanyak 366 studi di eksklusi karena tidak memenuhi kriteria yang sudah ditetapkan sebelumnya serta tidak relevan untuk topik yang dibahas. Hasilnya didapatkan sebanyak 5 studi yang selanjutnya disaring kembali untuk memastikan aksesibilitas reviewer terhadap data (penyaringan full-text dan kelengkapan data studi). Hasilnya seluruh studi tersebut memenuhi segala kriteria inklusi sehingga dijadikan sebagai studi inklusi yang selanjutnya akan dilakukan qualitative synthesis dari seluruh studi tersebut.

\section{B. Kriteria Studi Inklusi}

Data dari 5 studi inklusi dapat dilihat pada tabel 1. Keseluruhan jumlah partisipan memastikan aksesibilitas reviewer terhadap data (penyaringan full-text dan kelengkapan data studi). Hasilnya seluruh studi tersebut memenuhi segala kriteria inklusi sehingga dijadikan sebagai studi inklusi yang selanjutnya akan dilakukan qualitative synthesis dari seluruh studi tersebut.

\section{Kriteria Studi Inklusi}

Data dari 5 studi inklusi dapat dilihat pada tabel 1. Keseluruhan jumlah partisipan studi inklusi adalah sebanyak 362 sampelhewan coba yaitu tikus. Seluruh sampel dalam studi inklusi mengalami atau dikondisikan untuk mengalami cidera otak. Seluruh studi inklusi menilai ekspresi protein GLT-1, 3 studi inklusi mengukur fungsi kognitif serta kondisi edema serebral, sebagai luaran dari intervensi yang diberikan. 
Tabel 1 Karakteristik

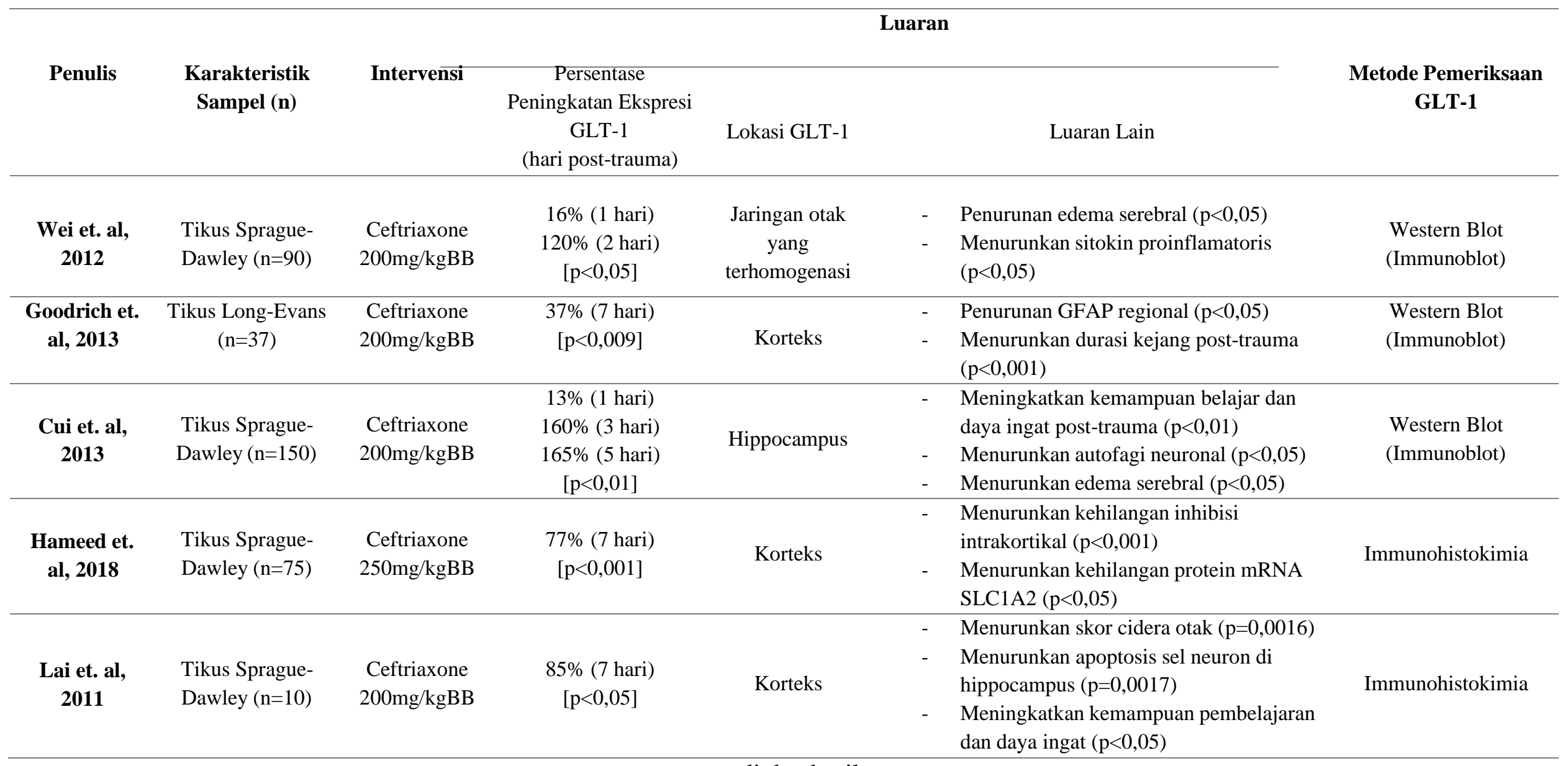




\section{Pembahasan}

\section{A. Peningkatan GLT-1 pada cidera otak}

Eksitotoksisitas selama ini dikenal sebagai salah satu proses penting yang terjadipada kematian sel pada cidera kepala akut (Aritonang et al., 2018). Kondisi ini disebabkan oleh pelepasan glutamat berlebih yang menstimulasi reseptor $\mathrm{N}$ metil-D-aspartat (NMDA). Banyaknya glutamat yang berikatan dengan reseptor NMDA akan memicu influx $\mathrm{Ca}^{2+}$ kedalam sel sehingga akan terjadi aktivasi dari berbagai enzim yang calcium-dependent. Aktivasi dari berbagai enzim inilah yang diduga menjadi penyebab dari destruksi dari sel neuron pada TBI. GLT-1 berperan dalammenjaga kadar glutamat agar tidak terlalutinggi dengan cara menghilangkan glutamat yang dilepaskan pada sinaps (Shofiati, n.d.). Oleh karena itu, menjaga kadar GLT-1 dalam kondisi TBI akan sangat berguna bagi keberlangsungan hidup sel-sel neuron. Penelitian yang dilakukan oleh Goodrich, dkk mendapatkan bahwa terjadi penurunan kadar GLT-1 yang signifikan pada 7 hari setelah terjadinya Traumatic Brain Injury (TBI) (Hendriani, 2017). Penelitian tersebut membandingkan ekspresi GLT-1 pada kelompok TBI yang diberikan cairan salin normal dengan kelompok yang tidak mengalami TBI dan mendapatkan bahwa terdapat penurunan ekspresi GLT-1 sebesar $48 \%$ pada kelompok pertama $(\mathrm{p}=0,0006)$.

\section{B. Peningkatan ekspresi GLT-1 setelah pemberian ceftriaxone dibandingkandengan kelompok kontrol}

Pemberian ceftriaxone berpotensi untuk meningkatkan ekspresi GLT-1 pada tikus yang mengalami cidera otak atau Traumatic Brain Injury (TBI). Pada 1 hari post-trauma, pemberian ceftriaxone tampak tidak meningkatkan ekspresi GLT-1 secara signifikan, sepeti yang ditunjukkan oleh penelitian Wei et al., (2012) dan Cui et al., (2013) yang persentase kenaikannya hanya sekitar $13-16 \%$ ( $<<0,05$ dan $\mathrm{p}<0,01)$. Angka tersebutmengalami peningkatan pesat pada hari ke-2 dan ke-3 posttrauma menjadi $120 \%$ padahari ke-2 $(\mathrm{p}<0,05)$ dan $160 \%$ pada hari ke-3 $(\mathrm{p}<0,01)[12$, 13]. Persentase peningkatan ini tampak menetap hingga hari ke-5 $(\mathrm{p}<0,01)$ seperti yang dilaporkan pada hasil penelitian Cui et al., (2013). Pada hari ke-7, persentase peningkatan kadar GLT-1 mengalami penurunan. Penelitian yang dilakukan oleh Hameed et al., (2018) dan Lai et al., (2011) melaporkan persentase peningkatan kadar GLT-1 yang serupa yaitu sebesar 77\% ( $<<0,001)$ dan 85\% ( $<<0,05)$. Sedangkan penelitian yang dilakukan oleh Goodrich et al., (2013) melaporkan persentase yang cukup berbeda dari dua peneliti sebelumnya dengan persentase peningkatan hanya sebesar $37 \%(\mathrm{p}<0,009)$. Perbedaan ini diduga sebagai akibat dari perbedaan spesies sampel yang digunakan oleh Hameed et al., (2018) dan Lai et al., (2011) yang menggunakan tikus sprague-dawley dengan Goodrich et al., (2013) yang menggunakan tikus long-evans. Dugaan lain adalah dikarenakan metode pemeriksaan yang digunakan untuk mengukur kadar GLT-1 yang digunakan oleh Hameed et al., (2018) dan Lai et al., (2011) (Imunohistokimia) berbeda dengan yang digunakan oleh Goodrich et al., (2013) (western blot atau immunoblot). Namun, 
meskipun terdapat perbedaan yang cukup signifikan, seluruh data yang dilaporkan tetap menunjukkan tren peningkatan kadar GLT-1 pada sampel yang diberikan intervensi ceftriaxone (Lai et al., 2011).

Hal menarik didapatkan pada hasil penelitian dari Hameed et al., (2018) dan Lai et al., (2011). Hameed et al., (2018) menggunakan intervensi dengan dosis ceftriaxone yang lebih tinggi $(250 \mathrm{mg} / \mathrm{kgBB})$ sedangkan intervensi yang dilakukan oleh Lai et al., (2011) dengan dosis (200mg/kgBB)ternyata memberikan luaran yang bertolak belakang. Persentase peningkatan yang didapatkan oleh Hameed et al., (2018) (77\%, p<0,001) lebih rendah dibandingkan dengan persentase yang didapatkan oleh Lai et al., (2011) (85\%, p<0,05). Hal ini memerlukan investigasi lebih lanjut di masa yang akan datang terkait dosis pemberian ceftriaxone yang berbeda terhadap peningkatan ekspresi GLT-1 (Hameed et al., 2019).

\section{Respon ekspresi GLT-1 pada bagian otak yang berbeda terhadap pemberianceftriaxone}

Berdasarkan 5 studi inklusi yang dilibatkan dalam kajian sistematis ini, kami menemukan bahwa terdapat peningkatanyang signifikan pada ekspresi protein GLT1 pada berbagai bagian otak yang diteliti. Peningkatan tertinggi didapatkan pada hippocampus dengan persentase peningkatan sebesar lebih dari $150 \%(\mathrm{p}<0,01)$ (Cui et al., 2013). Hippocampus juga sekaligus menjadi lokasi dengan persentase peningkatan terendah dibanding lokasi lain pada hari pertama dengan persentase peningkatan yang hanya sebesar $13 \%(\mathrm{p}<0,01)$. Selain hippocampus, 3 studi yang dilakukan oleh Goodrich et al., (2013) ; Hameed et al., (2018) ; dan Lai et al., (2011) melakukan pengukuran kadar GLT-1 pada bagian korteks serebri 7 hari post-trauma dengan hasil yang telah dibahas sebelumnya. Sayangnya, penelitian oleh Wei et al., (2012) tidak menjelaskan secara spesifik bagian otak mana yang digunakan untuk melakukan pengukuran kadar GLT-1 namun hanya menyebutkan bahwa mereka menggunakan jaringan otak yang terhomogenasi. Efek pemberian ceftriaxone terhadap penurunan edema serebral

Dari 5 studi inklusi, terdapat 2 studi yang mengobservasi efek pemberian ceftriaxone terhadap penurunan edema serebral post-trauma yaitu penelitian yang dilakukan oleh Wei et al., (2012) dan Cui et al., (2013). Kedua penelitian tersebut mengukur edema serebral dan penurunannya sebagai respon dari pemberian ceftriaxone dengan cara mengukur kadar air dalam otak (brain water content). Sayangnya, satuan yang digunakan oleh kedua peneliti tersebut berbeda sehingga tidak memungkinkan untuk dilakukan perbandingan secara kuantitatif. Penelitian yang dilakukan oleh Wei, dkk melaporkan terjadi penurunan kadar air dalam otak sebesar $\pm 1 \mathrm{~g} / \mathrm{g}(\mathrm{p}<0,05)$ pada 1 hari post-trauma sedangkan Cui, dkk melaporkan terjadi penurunan sebesar $\pm 2 \%(\mathrm{p}<0,05)$ pada 1 hari post-trauma. Namun, hal yang bisa disimpulkan dari kedua penelitian ini adalah bahwa pemberian ceftriaxone, jika dibandingkan dengan kelompok kontrol yang diberinkan cairan salin normal, mampu menurunkan edema serebral yang terjadi post-trauma. 


\section{Kesimpulan}

Sebagai kesimpulan, kajian sistematik di atas menunjukkan kemampuan neuroprotektif ceftriaxone pada kasus cidera otak. Secara keseluruhan, studi-studi inklusi menunjukkan bahwa ceftriaxone efektif dalam meningkatkan ekspresi GLT-1 diberbagai bagian di otak dalam 1-7 hari post- trauma, serta memperbaiki edema serebralyang terjadi dan meningkatkan kemampuan belajar serta daya ingat pada kasus cidera otak. Oleh sebab itu, hasil kajian sistematik ini mendukung penggunaan ceftriaxone dalam penanganan kasus cidera otak dikarenakan efek neuroprotektif yang dimilikinya. Dengan demikian, diharapkan hasil kajian sistematik ini dapat menjadi dasar penelitian lebih lanjut ke manusia sehingga kedepannya dapat mengurangi morbiditas dan mortalitas akibat cidera otak. Kami menyarankan dilakukannya penelitian uji keamanan dan selanjutnya uji klinis acak dengan jumlah sampel yang adekuat padasampel manusia untuk dapat lebih jauh mengonfirmasi hasil-hasil tersebut. 
Baiq Anggia Azzahra Halba, Abiyyu Didar Haq, Alifia Firdiansari, Harie Sagita Novendi

\section{BIBLIOGRAFI}

Abi Nubli, M. (2019). Depresi Pada Penderita Cedera Kepala. Jurnal Ilmiah Kesehatan Sandi Husada, 8(2), 207-211. Google Scholar

Aritonang, C. R. L., Retnaningsih, R., \& Husni, A. (2018). Hubungan Kadar Neuron Specific Enolase Serum Terhadap Luaran Klinis Neurologis Pasien Stroke Iskemik Akut. Majalah Kedokteran Neurosains Perhimpunan Dokter Spesialis Saraf Indonesia, 36(1). Google Scholar

Bahuddin, B. (2021). Intervensi Stimulasi Morottal al-Qur'an pada Pasien Cedera Kepala Berat dengan Penurunan Kesadaran di RSUD Labuang Baji Makassar. Universitas Islam Negeri Alauddin Makassar. Google Scholar

Estri, S. A. T. S., \& Radiono, S. (2007). Selulitis Fasialis dengan Trombosis Sinus Kavernosus. Mutiara Medika: Jurnal Kedokteran Dan Kesehatan, 7(1), 51-56. Google Scholar

Farihatini, T. (2019). Environmental Impact on Human Health and Sustainable Development: A Comprehensive Study on Drinking Water Quality and Severity of Dental Caries in School Children in South Kalimantan Province, Indonesia. Griffith University. Google Scholar

Georges, A., \& Das, J. M. (2021). Traumatic brain injury. StatPearls [Internet]. Google Scholar

Hameed, M. Q., Hsieh, T.-H., Morales-Quezada, L., Lee, H. H. C., Damar, U., MacMullin, P. C., Hensch, T. K., \& Rotenberg, A. (2019). Ceftriaxone treatment preserves cortical inhibitory interneuron function via transient salvage of GLT-1 in a rat traumatic brain injury model. Cerebral Cortex, 29(11), 4506-4518. Google Scholar

Hendriani, W. (2017). Adaptasi positif pada resiliensi akademik mahasiswa doktoral. Humanitas: Jurnal Psikologi Indonesia, 14(2). Google Scholar

Hidayati, O. N. U. R. (2015). Studi Penggunaan Antibiotika Pada Pasien Meningitis Bakteri Penelitian dilakukan di Instalasi Rawat Inap Departemen Ilmu Penyakit Saraf RSUD Dr. Soetomo Surabaya. Universitas Airlangga. Google Scholar

Lai, P. C., Huang, Y. T., Wu, C. C., Lai, C.-J., Wang, P. J., \& Chiu, T. H. (2011). Ceftriaxone attenuates hypoxic-ischemic brain injury in neonatal rats. Journal of Biomedical Science, 18(1), 1-10. Google Scholar

Poole, D., Chieregato, A., Langer, M., Viaggi, B., Cingolani, E., Malacarne, P., Mengoli, F., Nardi, G., Nascimben, E., \& Riccioni, L. (2014). Systematic review of the literature and evidence-based recommendations for antibiotic prophylaxis in trauma: results from an Italian consensus of experts. PloS One, 9(11), e113676. Google Scholar

Rimmele, T. S., \& Rosenberg, P. A. (2016). GLT-1: the elusive presynaptic glutamate 
transporter. Neurochemistry International, 98, 19-28. Google Scholar

Sepkuty, J. P., Cohen, A. S., Eccles, C., Rafiq, A., Behar, K., Ganel, R., Coulter, D. A., \& Rothstein, J. D. (2002). A neuronal glutamate transporter contributes to neurotransmitter GABA synthesis and epilepsy. Journal of Neuroscience, 22(15), 6372-6379. Google Scholar

Shofiati, S. (n.d.). Pengaruh Ekstrak Kayu Manis (Cinnamomum cassia) terhadap Glukosa Darah, Berat Badan, serta HDL Tikus Diabetes (Sprague dawley) yang Diinduksi Aloksan. Google Scholar

Suhery, W. N., Fernando, A., \& Has, N. (2016). Uji aktivitas antioksidan dari ekstrak bekatul padi ketan merah dan hitam (Oryza sativa L. var. Glutinosa) dan formulasinya dalam sediaan krim. PHARMACY: Jurnal Farmasi Indonesia (Pharmaceutical Journal of Indonesia), 13(1), 101-115. Google Scholar

\section{First publication right:}

Jurnal Syntax Fusion: Jurnal Nasional Indonesia

\section{This article is licensed under:}

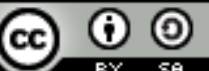

